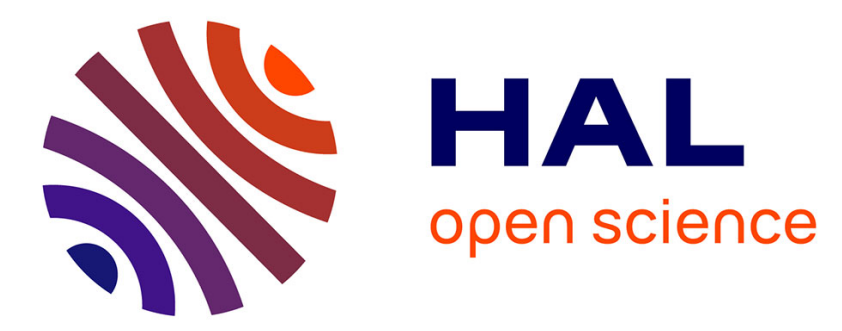

\title{
The Culture of Marginality: The Teenek Portrayal of Social Difference
}

Anath Ariel de Vidas

\section{To cite this version:}

Anath Ariel de Vidas. The Culture of Marginality: The Teenek Portrayal of Social Difference. Ethnology, 2002, 41 (3), pp.209-224. 10.2307/4153026 . hal-03303691

\section{HAL Id: hal-03303691 \\ https://hal.science/hal-03303691}

Submitted on 3 Aug 2021

HAL is a multi-disciplinary open access archive for the deposit and dissemination of scientific research documents, whether they are published or not. The documents may come from teaching and research institutions in France or abroad, or from public or private research centers.
L'archive ouverte pluridisciplinaire HAL, est destinée au dépôt et à la diffusion de documents scientifiques de niveau recherche, publiés ou non, émanant des établissements d'enseignement et de recherche français ou étrangers, des laboratoires publics ou privés. 
The Culture of Marginality: The Teenek Portrayal of Social Difference

Author(s): Anath Ariel de Vidas

Source: Ethnology, Summer, 2002, Vol. 41, No. 3 (Summer, 2002), pp. 209-224

Published by: University of Pittsburgh- Of the Commonwealth System of Higher Education

Stable URL: http://www.jstor.com/stable/4153026

JSTOR is a not-for-profit service that helps scholars, researchers, and students discover, use, and build upon a wide range of content in a trusted digital archive. We use information technology and tools to increase productivity and facilitate new forms of scholarship. For more information about JSTOR, please contact support@jstor.org.

Your use of the JSTOR archive indicates your acceptance of the Terms \& Conditions of Use, available at https://about.jstor.org/terms 


\title{
THE CULTURE OF MARGINALITY: THE TEENEK PORTRAYAL OF SOCIAL DIFFERENCE ${ }^{1}$
}

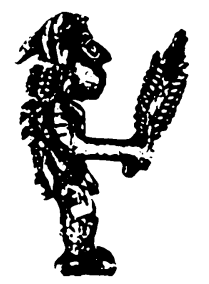

\author{
Anath Ariel de Vidas \\ University of Haifa
}

\begin{abstract}
The marginality of the Teenek Indians of Mexico gives rise to discourses among this group that serve to justify its relegation to the fringes of modern life. Those discourses reflect a concrete, inexorable, social, economic, and political situation that is reformulated in the Teenek system of representation. This article explores the problem of constructing an ethnic identity as it is reflected in the realities and world views of the indigenous microcosm facing national society. (Mexico, Teenek [Huastec] Indians, ethnicity, world view)
\end{abstract}

The Teenek Indians in northeastern Mexico are notable for a peculiar attitude that combines a state of apparent deculturation with a particularly self-deprecating discourse: "We are less than nothing," "stinking," "dirty Indians," "ugly idiots," "cowards," etc. These rather unexpected opinions were collected during my fieldwork in several Teenek villages, particularly the village of Loma Larga-San Lorenzo, near the town of Tantoyuca, in the northern part of the State of Veracruz. ${ }^{2}$ Two and a half years' residence in the area, from March 1991 to September 1993, was augmented by shorter visits up to November 1995. Teenek self-denigrating indigenous discourses are recurrent and common to people of both sexes, different ages, and in different places. The startling contrast they offer to the assertions of ethnic identity and the search for roots so prevalent today around the world invites analysis of the discursive construction of the social categories they express. Indeed, as Levine (1999) suggests, ethnicity stems above all from a cognitive method of classifying human beings. Accordingly, my research explores the elaboration of a disconcerting ethnic identity by examining the realities and conceptions of the indigenous microcosm vis-à-vis national society (Ariel de Vidas 2002).

The self-denigrating remarks such as those mentioned tend to justify the social and spatial marginality of the Teenek with respect to their mestizo neighbors. Most of these non-Indians, whom the Teenek consider to be better off than themselves, live in the town nearby, and represent for the Indian population both the positive aspects (modernity, power, money, etc.) and negative aspects (betrayal of tradition, immorality, greed, etc.) of Western culture. Although the Teenek lack such emblematic Indian traits as traditional clothing, agricultural rituals, distinctive ceremonies, and a system of religious offices (the cargo system), their situation is not one of anomie, since as a group they have preserved their language and a cosmology rooted in the Mesoamerican tradition. Thus, while the Teenek are primarily negative in their remarks about themselves, this discourse does not imply a weak sense of belonging. In a way, these autochthonous comments justify the group's marginal position and reflect a cultural construction of Teenek identity in which the disparities between social groups, which in the Teenek view arise from ontological differences,

ETHNOLOGY vol. 41 no. 3, Summer 2002, pp. 209-24. 
are negotiated. Thus, the Teenek possess a strong ethnic identity that does not appear, a priori, to be based on any validating, reclaimed heritage, but which, on the contrary, seems to derive from negatively perceived values.

The construction of an ethnic identity has long been dominated in the anthropological literature by the essentialist point of view, which emphasized self-definition and ethnogenesis as the factors that demarcated a specific culture, language, and customs (Geertz 1963; Shils 1957; Francis 1976). With Barth's critical revision (1969) of the ways ethnic groups maintain their ascription, the subject took on a perspective that permits an analysis of ethnification (Pitt-Rivers 1965, 1967; Casagrande 1974). In this approach, the formation of ethnic groups was seen to be a function of the political, economic, or ideological domination of one group by another, and a constantly renewed codification of cultural differences between distinct social groups (Cardoso De Oliveira 1992). However, through the operation of a dialectical effect, ethnic groups defined as such by external circumstances often take up an ethnic identity in order to press political or economic claims, while stressing essential traits as the basis for that identity (see Wolf 1994; Fischer 1999). This phenomenon raises the problem of whether the claimed ethnicity is different in nature from the one imposed by various external processes (Boege 1988; Warren 1992). Is it a manipulated new archaism or a new ideological alternative? As a way out of this dilemma, the current approach to ethnicity presumes that an ethnic group exists only inasmuch as it is a factor in the thinking and actions of both the group's members and outsiders (Augé 1987; Taylor 1991). Despite a certain return to substantivism to explain ethnic configuration (Fischer 1999; Gil-White 2001; Mahmood and Armstrong 1992), essentialist and constructivist approaches are now combined to some degree to understand the process of elaborating an ethnic identity (Field 1994; Jenkins 1997).

With the Teenek, this processual approach is indeed necessary, as their ethnic identity is not expressed in political claims but rather in strong negative descriptions of themselves, which are presented as the only basis for their collective cultural identity. Accordingly, this essay explores the Teenek ethnotheoretical model of identity through the realities and world view of the indigenous microcosm that faces national society from its margin. Based on a "cultural logic" (Fischer 1999), defining themselves as marginal is more a way of situating themselves in a multiethnic social universe than it is a subordination to the Other.

\section{CHICKENS VERSUS TURKEYS}

As this article deals particularly with the question of social marginality and how marginalized people deal with their situation, how should marginality be defined? In the social sciences, a cultural minority group's economic and social marginality is usually viewed as the result of a deviation from the norm and an instance of nonintegration into the majority society or as the result of deracination. Moreover, since marginality is defined in relation to a normative center, studies of the subject 
often focus on situations of urban poverty and social maladjustment. In such studies, marginality may be analyzed in terms of maintaining minority subcultures and traditional solidarities, in accordance with Lewis's $(1959,1966)$ concept of the culture of poverty, or else as a phenomenon "structurally linked to the capitalist system" (Marie 1981; Leacock 1971).

Beyond the perception of a minority group's marginality as deviance or as a consequence of historical processes and social stratification (based on inequality, not ethnicity), the fringes of the majority society can also be viewed as a place for the cultural construction of difference. The Teenek Indians' discourse that justifies for them their exclusion from the adjacent modern society reflects a situation that is resemanticized in the Teenek system of representation. Thus we take the perspective of the indigenous group and approach its history through the prism of its own world view.

For example, the following instance of Teenek self-denigration manifested in their language shows how the group's subordinate position is internalized by its members. The Teenek term for mestizos is ejek (Spaniard), the same word they use for turkeys; whereas they call chickens teenek, the name they use for themselves. Since turkeys are autochthonous birds, it would seem more logical to give them the name of the indigenous people, and to call chickens by the name of their importers, the Spaniards. However, the Teenek reasoning is different: "Baby turkeys, raised on corn mash, are clean and eat only from the palm of the hand, so they must be served, just as the ejek-the mestizos and masters-are served. Chickens, in contrast, peck their food directly from the ground, and will eat any old garbage, anywhere, like the Teenek." Another explanation is: "The ejek always want to be waited on; they expect to be given their food on a plate with a knife and fork, while the Teenek will eat anything, anywhere, to fill their bellies. ${ }^{3}$ According to other versions, the name refers to the more fragile nature that turkeys share with mestizos, who are considered more vulnerable to inclement conditions and strain. (The same logic explains why mestizos work less than Teenek people.) When a turkey is struck, it falls down, becomes sick, and has to be nursed back to health, whereas chickens, like the Teenek, can be hit with no adverse effects. Turkeys are considered violent and, like the mestizos who behave aggressively toward the Teenek, are constantly attacking chickens; but chickens, like the Teenek, stand fast. A final example of the use of fowl as a metaphor is that of a Teenek woman whose husband had brought her four battery hens from town. She said that the chickens did not understand her calls in Teenek because, coming from "civilization," they understood only "pretty talk" (oyen sólo bonito). These versions characterize the relationship between the ejek and the Teenek as one of unequal power. However, for a proper grasp of the acuteness of this kind of discourse, we must first examine the social and spatial configuration of the spheres in which it develops. 


\section{A TALE OF COWBOYS AND INDIANS}

The Huasteca, a richly fertile region well suited to agriculture in the humid tropical zone of northeastern Mexico, has seen colonization since the arrival of the Spaniards. As such, it has experienced the classic antagonism that pits farmers against ranchers. In this case, the conflict began with the despoilment of Indian lands by the Spanish colonists and later their mestizo descendants. The appropriation of Indian lands for cattle ranges continues today by various means, including violence (Ariel de Vidas 1994a). This agrarian history has left its mark on the countryside, where today large estates border on patchy small holdings. Indian lands have thus been greatly reduced, but over the centuries the Teenek have managed to recover some of the usurped territory by seizing opportunities as they arose (Ariel de Vidas 2002). Today's Teenek communities, scattered around the mestizo town of Tantoyuca, are the result of these efforts, and they constitute the social framework that has preserved this ethnic group.

The appearance of this region of exuberant tropical vegetation is deceptive. Beyond the luxuriant natural landscape, the peasants eke out a living in a subsistence economy dictated by the scarcity of arable land and the consequent exhaustion of existing farm plots. Closer examination of the area shows that large, flat expanses are devoted to cattle-raising, while hilly land is much more likely to be divided into small plots planted with corn and beans, as well as agave (used by local craftsmen).

Indian villagers ( 57.5 per cent of the population of the Tantoyuca municipio) are in the hills, where there are many fewer mestizo peasants (16 per cent). These hill settlements are usually remote, isolated hamlets lacking services such as piped potable water, electricity, medical assistance, roads, and communication media. Housing consists of bamboo huts (sometimes plastered with cob) with palm-leaf roofs and hard-packed dirt floors. A single room often serves many purposes: living room, kitchen, dining room, bedroom, and storeroom for ears of corn. Most of the homes have no latrines, and water is obtained from putrid, stagnant pools, or streams sometimes more than an hour's walk away.

While the hills surrounding the town of Tantoyuca are covered with the clustered hamlets and small holdings of mestizo and Indian peasants, the plains just below them are nearly empty, except for a sprinkling of cattle ranches. More particularly, the flat land to the northeast of Tantoyuca is part of a territory, measuring some 400,000 hectares, that constitutes the largest expanse of private property in the state of Veracruz (Cambrezy 1991:34). These lands are devoted exclusively to large-scale cattle ranching, and this part of the Huasteca region accounts for 40 per cent of all cattle-raising in Veracruz, which itself is the leading stock-breeding state in the nation (Barrera and Rodríguez 1993).

The lands acquired by the Teenek before the agrarian reform are currently subject to the communal land-tenure system. The domination of the Tantoyuca area by ranchers and their powerful political allies is related to the fact that not many postrevolutionary ejidal land grants were made in this area, allowing the big ranches 
to gobble up Indian lands. The deforestation inherent in extensive cattle-raising also erodes the land and creates an ecological imbalance that affects the natural environment of the Teenek. Moreover, as farmland is scarce and overworked, its productivity declines. At the same time, the population growth of recent decades has forced the Teenek out of their communities to look for day or seasonal work in the region, putting them in constant contact with both the non-Indian society that exploits them and the inexorable realization of their own marginal status.

The contrast between wealth and poverty is striking. Tantoyuca is among the top 25 per cent of the most marginalized Mexican districts (Consejo Nacional de Población 1993). In this region where the social hierarchy is based on ethnic affiliation, the Teenek, who in 1995 constituted about 52 per cent of the population of the Tantoyuca municipio $(46,500)$, are on the lowest level. Descendants of the Huastec, they have been subjugated and acculturated twice: first by the Aztecs and later by the Spaniards and Western civilization. As a result, the ethnic traits and characteristics of ancient Huastec society have gradually been obscured over the course of generations. Yet today this group presents a rare profile combining apparent acculturation and self-denigration with a strong sense of ethnic identity that is sustained precisely by the group's extreme political, economic, and cultural marginality. The disparities that pit the mestizo ranchers against the Indian farmers have deep roots in this local society, and ultimately provide a key to understanding the Teenek perception of themselves.

\section{TEENEK IDENTITY}

The dozen or so kilometers separating most of the Teenek villages from the Tantoyuca urban center cover an abyss of mutual ignorance between their two worlds. Although the Teenek visit Tantoyuca regularly, they have no social relations with the town's inhabitants other than trade and the sale of their labor. The members of each of the two societies have thus constructed their own set of representations of the human group that lives so near, yet is so remote. Consequently, the Veracruz Teenek live both in constant contact with and cut off from mestizo society, a life that is articulated around a fundamental social division that separates, in the terms of the local language, "the city people" from the "people of the communities." This expression is not merely a rhetorical device. It forges the modes of representation that are shared in practice by the social actors on both sides of the divide. The two aspects of this division can equally include other terms used on a daily basis. Thus, "the mestizos," "the Spaniards," "the gente de razón" (people of reason), "the cattlemen," "the people with cars," "the rich," and so on, live in the city; whereas "the Indians," "the inditos," "the huastequitos" (both pejorative diminutives), "the natives," "the gente sin razón" (people without reason), "the kwitol" (Teenek, child), and "the people of humble origin" live in the communities.

This dichotomy, lived and perceived daily by all the social actors as a cultural clash-even if it is superimposed on other kinds of distinctions, essentially social, 
economic, and territorial-supports the Teenek perception of their identity as themselves versus the Others. The boundary thus created, as Barth (1969) points out, is a means of defining the ethnic group and determining its continuity independent of its cultural content, which itself remains variable. Accordingly, ethnicity is a form of social organization based on the demarcation of groups according to their ascribed origin. The different diacritical marks established by each group then confirm the nature of the group's social interaction.

The ethnic aspect of this dichotomy is reflected in the way the Teenek entrench themselves in their communities, the filter that their authorities put up between the mestizo and Teenek worlds, their practice of local endogamy, and the various devices they employ to preserve their collective territorial patrimony. The community space, where Teenek is spoken, where certain Indian customs are still practiced, where people from outside the community (especially mestizos) are excluded, and where mechanisms of incorporation imply the actual presence of the community's inhabitants (Ariel de Vidas 2002), thus becomes for the latter a place that offers emotional attachment and refuge against a rather inhospitable external world. Membership in the ethnic group appears as an effective way of defending advantages (land, relative autonomy, customary law, etc.) and of overcoming social, political, and economic disadvantages through solidarity and shared circumstances. In cases of continuous interaction between separate cultural groups, as Glazer and Moynihan (1975:15-16) suggest, ethnicity emerges as a counter to the social stratification that arises from the history of each group. But what is the basis for assuming this ethnic identity?

\section{THE MYTH OF ORIGIN}

One of the formal requirements for full-fledged membership in the Teenek community is patrilineal descent. Unlike other forms of collective identity, ethnic identity is based essentially on the subjective belief in a shared blood relationship (Weber 1968:385-98). The common descent assumed by an ethnic group implies the development of a collective history, invented or experienced, which by invoking some seminal event molds the group and validates the sense of belonging to it. Thus, the Veracruz Teenek identify with a myth of origin that explains the social and economic boundaries that separate them from other groups and ultimately relegate them to marginality. This myth goes back to a remote period when the earth was flat and the sun did not yet exist. When it finally appeared, the ancestors of the Teenek rejected it and buried themselves in the earth, creating mountains and ravines that would hide the sun. This attempt to obscure the light of day failed, and in the end the Teenek ancestors remained in the subterranean shadows, angry with the human descendants who inhabited their former territory. These tellurian beings are called Baatsik' (whirlwinds). Whenever contemporary Teenek behave in a way judged excessive with respect to the Baatsik' or the members of their community, these beings of the underworld appear in the form of winds and cause "diseases of the 
soul.” The punishment of excess by misfortune thus represents a certain calling to order which is at the same time a reminder of common origin and collective memory. Masters of the earth, the Baatsik' are thus the guardians of Teenek territory in its broadest sense.

When a Teenek is stricken with illness sent by the presolar ancestors, redemptive measures must be undertaken to appease the Baatsik'. Besides special invocations made in the Teenek language, these measures include leaving under certain trees offerings of special dishes that are delicious to tellurian beings but disgusting to humans. The Baatsik' like refuse, spittle, foul-smelling, dirty, raw, rotten, or tasteless food, chicken heads, eggshells, bones, carrion, and especially brandy (mixed with saliva if possible). These preferences are complemented by the Baatsik' predilection for nighttime activity, making their behavior in all respects completely opposite to that of humans. The Baatsik' lurk in places where the earth's crust is uneven; i.e., in the mountains and ditches that they themselves created by burying their heads in the ground at the approach of the sun. In daily life, the Teenek are very attentive to these places, which are a constant reminder of their creation story. Conscious of occupying a territory that is not their own, they know that encounters with these permanently malevolent chthonian beings are inevitable. Accordingly, they have organized a complete separation between themselves and the Baatsik', drawing a line between domestic space, sanctified by images of Catholic saints, and wild space, the domain of the pagan divinities.

In Teenek thought, the reality of the Baatsik' functions as a principle of alterity and subordination. The advent of "the light" separated these prehuman ancestors from modern Teenek and thereby established the initial pair of opposites, setting up the "we" of the present against the "others" of the past. This "otherness" is a basic part of Teenek identity, since the Baatsik', as ancestors, are the creators of Teenek history. Moreover, even while belonging to another place, the Baatsik' remain the guarantors of Teenek morals through the mechanism of illnesses that often strike the Teenek because of social lapses. Thus, alterity is not opposite to the self but is in the self; and it is so closely associated with Teenek identity that it is imprinted in the body of every individual. Those others must be shown respect to avoid inciting their fury.

Harmonious coexistence between the Teenek and the Baatsik', then, is founded on the principle of respect, moderation, and reciprocity. The right of Teenek to live on the lands of their ancestors is accompanied by a principle of moderation and respect for difference (expressed in the offerings to the chthonian beings and respect for their territory). The reciprocal relationship that results legitimizes the Teenek demand to live on the land of their prehuman ancestors and, in a sense, under their protection. Consequently, relations between the Teenek and the creatures of nature are based on terms of coexistence, which are fundamental to Teenek identity. These terms also apply to Teenek relations with their social Others: non-Teenek peoples. 


\section{MARGINALITY AS SEEN BY THE TEENEK}

Virtually nothing is known of the history of the Teenek people. Beyond general information at the regional level, archival documents from the end of the nineteenth century are the earliest evidence for any reconstruction of Teenek history (Ariel de Vidas 1994b). The historical memory of the Teenek goes back only to the time of the Mexican Revolution, the beginning of the twentieth century. Yet they are not a people without history, for the story of the Baatsik' integrates the historical memory and forms, ultimately, the Teenek representations of social difference. This story constitutes a Teenek manifesto that offers them a key to understanding their spatial and social position with respect to mestizos, ranchers, the affluent, city dwellers, more prosperous Nahua Indians, and so on. Three examples below show how the myth of origin influences the Teenek conception of marginality. The first concerns the Teenek explanation for their peripheral position.

\section{Periphery and Center}

[B]efore we were conquered by the Spaniards, we [were] poor people. The Teenek lived naked, they were not baptized, when Christopher Columbus and Fernando Córtez came, they were not eating well, they lived on roots. They knew nothing, their food was not cooked. The Spaniards brought teaching, they taught the poor people. The Teenek had no houses, they lived like deer, like rabbits. There were only houses and people in the city of Mexico. Here there was nothing, no houses, no little villages, they lived naked, in caves, under rocks, in ditches. The Spaniards taught them to talk, they baptized them, they taught them how to eat. That is how it happened, that is how the village came to be. They united everybody with them. People who did not want to join with those from outside remained like we are, outside. They did not want to live near the road. They did not want to go with the mestizos. They don't understand, don't know how to talk, they are afraid of being killed. Here the mestizos did not come. Here people close the doors, they don't answer, they hide in the brush, for fear of being killed. It is the custom of the ancestors. Now we've hardly given up this old custom, that's why it's still half-wild here. . . . (Dionisio Cruz Hilaria, Loma Larga, San Lorenzo, 1993)

This testimony shows quite unequivocally the Teenek identification with a good many of the attributes of the Baatsik'. According to the account given above, before the arrival of the Spaniards and the cultured world, Teenek were unclothed and unbaptized, ate raw food like the Baatsik', and were like the wild animals they herded. They lived in the same places preferred by the Baatsik', in caves, under rocks, and in hollows. Having no houses, they were exposed to the elements and the forces of nature. When the Spaniards arrived to civilize the Teenek, the latter remained, like their presolar ancestors, "outside"-which is their ethnic "inside."

The Teenek identification with the Baatsik' to explain their present marginalization seems to reveal a sense of inferiority and a blind veneration of the Spaniards and their descendants. From the testimony above it appears as though nothing existed before the Spaniards' arrival and Teenek society was still plunged in its primitive phase. Yet the absence of Teenek accounts of the pre-Hispanic period of the development of Huastec civilization (which lasted from 200 AD to the Spanish conquest in 1522) may be attributable not only to a lack of historical documents but 
also to a cultural construction. In effect, modern Teenek could in this way affirm an identity different (more civilized) from that of their prehuman ancestors, thereby distinguishing themselves from the latter without denying their kinship with them. That kinship constitutes a cornerstone of their identity, and their first alterity.

The rupture with the seminal past introduces a void between the prehuman era and recent times, and seems to have allowed the Teenek to accept the presence of the Spaniards as civilizing heroes, and their subjugation is probably perceived as the price to be paid for that enculturation. By placing the Spaniards' arrival immediately after the primitive phase of Teenek civilization, right at the beginning of social humanity, Teenek accounts of the arrival of the conquistadors rationalize mestizo domination and the relegation of Teenek to the fringes of modern society. But rather than merely reflecting a fatalistic view, these accounts also indicate the stubborn identification of the Teenek with their ancestors, in this case with their fearfulness. Faced with an unavoidable situation, the Teenek cling to their ethnic identity to cope with difference.

\section{Weak versus Strong}

An identification with the weaker element applies not only to the Teenek's relations with the conquistadors' descendants, but also to their relations with their previous conquerors, the Nahua, descendants of the Aztecs. This is made clear by the next example of the relation between the myth of origin and the Teenek perception of their marginality. According to the Teenek's interpretation of the Spanish Conquest (undoubtedly influenced by school textbooks), Moctezuma was king of the Teenek people because he was fearful and submissive, whereas Cuauhtemoc was king of the Nahua because he was much more courageous. It should be noted that according to official history, Moctezuma II (1480-1520), the Aztec emperor reigning at the time of the conquest, let the Spaniards into his empire because he believed them to be the man-god Quetzalcoatl and his followers, returning as prophesied to reclaim his kingdom. Later Moctezuma was stoned by his own people as they rose up against the conquistadors. As for Cuauhtemoc (1495-1525), Moctezuma's successor (after Cuitlahuac, who died of smallpox shortly after ascending the throne), he led a bloody struggle against the Spaniards but was ultimately captured by them and executed. He remains, however, in the Mexican collective memory as the symbol of the last Aztecs' implacable resistance to the invaders. This very positive national image of the Indian does have its niche in the Teenek system of representation, but only in association with the Nahua Indians. Nor is this a case of an intellectualized image of the Nahua as descendants of the Aztecs, since the Teenek, for their part, identify with the antihero of the Conquest, the Aztec emperor who fell victim to his dreams ("he was our king").

The issue here is, instead, a nebulous perception of what the term "Indian" means for the Teenek, who distinguish between various Indian peoples, which they know by specific names. The concept of "Indian" is an import that is exogenous to 
Teenek culture; and for them the term carries the same ambivalent overtones that it does in national society, with the added filter of their own way of thinking. The national Indian must be Nahua, according to the Teenek, because his image is so positive. Teenek identification with a king perceived as weak parallels and reflects the Teenek's identification with their prehuman ancestors, who retreated into the chthonian universe at the approach of strangeness, novelty, and superior strength.

\section{Farmers versus Ranchers}

Interpreting the mythic or historic past permits the Teenek to situate themselves within the social order. But the Mesoamerican myths have been joined by others from the Western mythical repertoire brought by the conquistadors. The next example shows how Teenek mythic syncretism and the autochthonous perception of history justify contemporary social disparities. According to the Teenek myth describing their creation, the sun was a hardworking orphan boy of humble origins, whereas the moon was the lazy scion of a good family. This is why the wealthy do not go out into the sun but prefer the freshness of nighttime, while the poor work in the sun all the time. The poor "go out to work in any temperature, when it's very cold or very hot. But we can stand it because we are descendants of Cain, who was a worker of the fields; he worked like us, with a hoe, he sowed corn. That's why we're poor. The rich are descended from Abel."

The Teenek version of the biblical story of Cain and Abel admirably integrates their concept of two forces (pagan and Christian) into the logic brought by the Spaniards. The story goes that one day Cain and Abel each burned offerings for God. But Cain, according to the Teenek version, offered only rotten produce, squash (the commonest of fruits), and flawed grains. The smoke of his oblation went straight down to the earth and never rose, for God did not appreciate the offering. Abel, in contrast, offered good meat, lambs, and the smoke rose nicely heavenward. It is important to note that the original Bible account (Gen. 4:1-5) makes no mention of smoke, nor does it refer to the quality of the offerings; it merely says, without elaborating, that God accepted Abel's offering, composed of "the firstlings of his flock," and rejected that of Cain, consisting of "the fruit of the ground." According to Teenek informants, however, the composition of Cain's offering-degenerate foods-explains the fact that the smoke went downwards, for the oblation was actually meant for the Baatsik', who of course like anything that is rotten. In the end, Cain murdered his brother and was punished by God, with the result that his fields were never again fertile. "Our land is now affected by a curse; all the crops fail," asserted one Teenek peasant.

In the Teenek version, as in the biblical story, Cain is considered the bad brother while Abel is the good one. Cain is a farmer and Abel is a herdsman, mirroring once again the opposition between the Teenek peasants and the mestizo cattlemen of the region. Thus, the sons of Adam and Eve, the first humans, are to the Teenek the originators of racial and social differences between people. Moreover, Cain, born 
before Abel, is like the Teenek people who arrived in the Huasteca region well before the Spaniards, another confirmation of their autochthony. Cain, condemned by God to leave his land after his murder of Abel, turned toward the eastern sun which has turned red ever since as it rises, stained by the bloodshed; and Cain's land, wherever it is, remains cursed.

Thus, in claiming that they are descended from Cain and the mestizos from Abel, the Teenek justify their inferior status vis-à-vis the mestizos. Their perception of both history and the present is therefore supported by their interpretations of sacred writings. Agricultural misfortune and the social and economic inequities that separate the Teenek farmers from the mestizo ranchers are explained by the different destinies of the two original brothers as inscribed in the sacred texts. This opposition between farmers and ranchers may also reflect the difference between the assimilatory mentality of a farmer, which adapts itself to the qualities of plants and is thus closer to nature, and the paternalistic mentality of a rancher, which adapts livestock to the rancher's needs, and is thus closer to culture (see Haudricourt 1962:40-50). This characterization corresponds with the Teenek view of the relationship between the mestizo ranchers as civilized people and the Teenek farmers as savages.

\section{MYTH AND IDENTITY}

The purpose of a myth of origin is to explain a historical situation by applying a social logic to it (Malinowski 1954:125-26). A myth reflects indigenous thought by combining the amnesiac memory of the group with its cosmology and historical and social facts in order to explain the group's current situation, especially its inconsistencies. Thus, interethnic contact does not necessarily obliterate one culture in favor of another. The Teenek are at a stage where the different cultural poles still appear very clearly, and contact with neighboring mestizos actually reinforces this differentiation of ethnic positions. Moreover, the Teenek language is the only means of communication with the Teenek presolar ancestors. When some informants wondered whether they should speak only Spanish to their children in order to help them integrate into mestizo society, they were actually engaged in an internal debate over the allegiance they owed their ancestors, an allegiance that had become the mark of Teenek identity.

The qualities attributed to the Baatsik' and their universe are thus associated with ancestral ties, the local topography, the nourishing earth, and the Teenek language. In short, Teenek autochthony and ethnicity, with which the Teenek link themselves by means of what is rotten, stinking, and disgusting, their position at the margins of society, as well as their self-denigration, hinder them from challenging the social order. They are acutely aware of its inequities and injustices. As one Teenek pointed out with regard to the stone houses some wealthy mestizos build, "Who knows how much the Tantoyuca millionaires owe, their buildings are probably all mortgaged, they must have asked for loans, and now they owe huge amounts of money, they are 
as poor as we are, for they have debts, it's the reason they don't pay us when we work for them or when we sell them merchandise."

These examples show that ethnicity is not always expressed in militant Indian demands for political, economic, territorial rights, or cultural reconquest (see Ariel de Vidas 2000). Ethnicity may also be a major internal concern, involving a preoccupation with the health of the soul, a perceived duty of transmission, a difficulty in living with overlapping cultures, a struggle against one's ancestors while acknowledging the bond of kinship with them, and a permanent effort to pacify contradictory forces. Teenek ethnicity lies at the core of their resistance to assimilation into the mestizo world and at the same time at the core of their distancing from their presolar ancestors, those baleful kin who forged the history of Teenek marginality.

\section{THE CULTURE OF MARGINALITY}

Although in cultural terms the Teenek justify their marginality by situating it in a symbolic ensemble that informs their identity, it is important to understand the nature of life on the fringes of national society. Marginality implies a social situation that is perceived in relation to another situation considered as central. Marginality is not separate from the mainstream, but adjoins it and is, in fact, a correlation of it. Thus, the Teenek are not outside of the national society since they participate in activities involving the center as day laborers, tradesmen, pupils, and victims of land-grabbing. Even if they do not fully participate in modern life, they are not totally detached from it. They know about and use modern technology, albeit at times in an odd or curious way. This is clear when they compare the power of a boulder to that of a fax capable of bringing a lost soul back from the remote location of a seasonal job, or when they learn that the Teenek are of "proto-Mayan origin" from hearing it on the radio. In their homes in the hills, the Teenek observe the life down on the plains that moves at a different rate from theirs, and exists in accordance with different values. But the marginal space that the Teenek occupy has become a culturally constructed place that demonstrates this group's vitality, despite its disparaging view of itself. The Teenek are not relegated to an uncivilized state, but rather appropriate it for identity purposes.

As noted, the Baatsik' myth explains misfortune and is thus the basis of the Teenek concept of person. The story concerns the eruption of violence in the autochthonous universe. That violence comes into play with every external attempt to include the Teenek in a broader social universe. Thus, according to the native logic, integration of the Teenek into national society and modern life inevitably reproduces violence: registering children in school is apt to turn them into oil that will later be sold in subsidized grocery stores; working outside the community is sometimes perceived as an imprisonment of the spirit in the chthonian world of the Baatsik'; building a road or drilling for oil in the area always requires (according to local rumors) a human sacrifice; and so on. In this realization of the violence and 
power exercised by the Others, the Teenek are unquestionably in a vulnerable position. The Baatsik' myth institutes the harsh alterity and the imbalance of power between the prehuman ancestors and the contemporary Teenek, and, as a metaphor of the Teenek condition, the myth also reflects the disparity between Teenek and mestizos. The Baatsik', as the constituent alterity of Teenek identity, are thus in accord with the group's retreat into itself. In order to thwart the possible harmful effects of both encounters with the Baatsik' and contacts with mestizo society, the Teenek remain on the fringes of modern society and exercise temperance in their daily life. Difference thus gives rise to deference.

By the same token, the realization of the power that the Others have over the Teenek is recreated in the cultural constructions concerning Teenek marginality. In claiming to be descendants of Cain-a fixed, vertical descent-Teenek attribute their unfortunate destiny to an exogenous fate, so different from that of Abel's descendants, the mestizo ranchers. However, Teenek kinship relations are organized around the horizontal axis of alliances (Ariel de Vidas, In Press a), so social ties are formed exclusively with Teenek people. Accordingly, exogenous social relations are created in a vertical line that situates the Teenek subordinate to other social groups, whereas endogamous relations are established on a horizontal axis that accentuates the internal solidarity of the group. These metaphors help explain the Teenek self-derogatory discourse in relation to others.

Thus the Teenek claim to be descendants of Cain as opposed to the mestizo descendants of Abel; claim to have had as king Moctezuma, the Aztec emperor who was destroyed by his dreams, instead of the courageous Cuauhtemoc, king of the Nahua; and can identify with chickens, which eat anything, anywhere, in contrast to the mestizos, associated with turkeys, which need special care and must always be served. Ostensibly, this would seem to be a fatalistic approach to the overwhelming asymmetry between the Teenek world and the mestizo world and the realization that the mestizo world brings cultural extinction to the weak. Yet such self-denigrating discourse should really be understood as an allegorical idiom that translates this realization into a strategy of cultural survival through marginality. For example, when in their birth ceremonies the Teenek call upon the chthonian beings to respect the newborn child, they undertake to respect the Baatsik' in return. Recognizing the malevolent power of these tellurian beings, the Teenek establish a clear boundary between the chthonian and human worlds, one founded on a mutual respect that guarantees their survival (Ariel de Vidas, In Press b). The same is true for relations with the mestizo world. In such relations Teenek values focus not on a power-based hierarchy, but on survival in a relationship of deference: "For us, the important thing is not to die of hunger; the other things are a luxury," a young Teenek told me concerning his decision to marry a Teenek woman and remain within his community, even though he owned no land there.

The "center" occupied by the mestizos is not the only place of power. In contradistinction to the modern world that has become the center, the call for a marginalized but autonomous autochthonous universe is reflected in the myths, the 
narratives, the Teenek classification of pagan and Christian, the beliefs, the dances, the healing rituals, and generally in Teenek praxis (Ariel de Vidas 2002). Thus, when the Teenek address the Catholic saints in Spanish and the tellurian spirits in Teenek, when they divide their space between the Christian and the pagan, when they allow certain dances into the church but not others, when they bring certain maladies to doctors and others to healers, they are not being inconsistent or torn between two creeds. Their lavish dualism reflects a behavioral ideal based on respect for difference. For the Teenek, marginality is a field of maneuver where they are uncontested, and where the relationship with the Other is understood in autochthonous terms.

The various beliefs combined in this way are seen as incompatible only by the modern world. The Teenek are mobile and constantly pass from one world to the other, thus professing two kinds of beliefs within a single, bipartite religion. It is undoubtedly here amid this ambiguity that something akin to what Scott (1990) calls "the hidden transcripts" resides. This term denotes subversive discourses and attitudes of subordinate social groups concerning the dominant group and expressed "offstage," and contrasts with the attitude of resignation shown to outsiders. The Teenek demand for a certain kind of recognition does not translate into discourses of revenge or millenarian visions of overturning the social order. Like other marginalized indigenous groups reduced to expressing their identity only through the unsaid, ${ }^{4}$ the Teenek claim to identity is expressed through the symbolic segregation that they establish between the pagan-autochthonous world and the Catholic-modern world. This segregation ultimately is a function of the choice to preserve Teenek cultural identity in a certain space which allows continuing the relationship between the Teenek and their prehuman ancestors who form the support for their ethnic identity. Teenek praxis is thus a muted language of subversion that is restricted to the circumscribed space that the Teenek retain on the fringes of the dominant society. In this way Teenek vulnerability is symbolically transformed into an art of resistance.

The Teenek space is not merely the space of marginalized memory, but also the arena for a cultural elaboration on diversity that responds locally to globalizing processes. The art of survival has thus established a close union between myth and praxis, transforming Teenek life on the edge of modern society into metaphor.

\section{NOTES}

1. This is a revision of an earlier essay entitled: “Je plie, et ne romps pas': La vision teenek de la marginalité et de l'ethnicité (Huastèque veracruzaine, Mexique)," published in Cahiers des Amériques Latines 25:79-96.

2. Research was supported by the French Ministry of Education (1990), the French Ministry of Research and Technology (1990-1993), the Mexican Foreign Affairs Ministry (1991-1993), and the Seminario de Estudio de la Cultura, CNCA, Mexico (1994).

3. Teenek people normally eat with "Moctezuma's spoon," a tortilla that they dip in a stew with their fingers or that they fill with black beans. On the very rare occasion that an ejek is present among the diners, he is given the only spoon in the house, that used for cooking. Civilization is thus expressed 
through signs that must be exhibited when the Other is present. Similarly, when Teenek people go into town, they "dress up" (a cleaner dress, a less ragged shirt, etc.).

4. Examples of this include the Pumé of Venezuela, who take refuge in their dreams (Orobitg Canal 1997), and the Dayaks of Indonesia, who parody their own marginality (Lowenhaupt Tsing 1993).

\section{BIBLIOGRAPHY}

Ariel de Vidas, A. 1994a. Un problème de limites: L'espace teenek dans la Huastèque veracruzaine. Géographie et Cultures 11:119-36.

1994b. La bella durmiente. El norte de Veracruz. Las llanuras costeras de Veracruz-la lenta construcción de regiones, eds. O. Hoffmann and E. Velázquez, pp. 39-73. Xalapa.

2000. The Teenek Indian and the Public Indian: Indians and the Public Spheres in Twentieth-Century Northeast Mexico. The Collective and the Public in Latin America: Cultural Identities and Political Order, eds. L. Roniger and T. Hertzog, pp. 257-72. Brighton. 2002. Le Tonnerre n'habite plus ici. La culture de la marginalité chez les Indiens teenek du Mexique. Paris. (English translation, in press: Thunder Doesn't Live Here Anymore: The Culture of Marginality among the Teenek, Mexico. Boulder.)

In Press a. El parentesco teenek. Familia y parentesco en México y mesoamérica: Unas miradas antropológicas, ed. D. Robichaux. Mexico City.

In Press b. El rito de nacimiento teenek: ¿reminiscencias de una práctica maya? Cuadernos del CEM. Mexico City.

Augé, M. 1987. Qui est l'autre? Un itinéraire anthropologique. L'Homme 103/27(3):7-26.

Barrera, N., and H. Rodríguez (eds.). 1993. Desarrollo y Medio Ambiente en Veracruz: Impactos económicos, ecológicos y culturales de la ganadería en Veracruz. Xalapa.

Barth, F. 1969. Introduction. Ethnic Groups and Boundaries: The Social Organisation of Culture Difference, ed. F. Barth, pp. 9-38. Boston.

Boege, E. 1988. Los mazatecos ante la nación-Contradicciones de la identidad étnica en el México actual. Mexico City.

Cambrezy, L. 1991. La distribución de la propiedad social en el estado de Veracruz. Geografía y Desarrollo 2(6):30-42.

Cardoso De Oliveira, R. 1992. Etnicidad y estructura social. Mexico City.

Casagrande, J. 1974. Strategies for Survival: The Indians of Highland Ecuador. Contemporary Cultures and Societies of Latin America, ed. D. Heath. New York.

Consejo Nacional de Población. 1993. Indicadores Socioeconómicos e índice de Marginación Municipal 1990. Mexico City.

Field, L. W. 1994. Who Are the Indians? Reconceptualizing Indigenous Identity, Resistance, and the Role of Social Science in Latin America. Latin America Research Review 29(3):237-48.

Fischer, E. F. 1999. Cultural Logic and Maya Identity. Rethinking Constructivism and Essentialism. Current Anthropology 40(4):473-99.

Francis, E. K. 1976. Interethnic Relations. New York.

Geertz, C. (ed.) 1963. Old Societies and New States. New York.

Gil-White, F. J. 2001. Are Ethnic Groups Biological "Species" to the Human Brain? Essentialism in Our Cognition of Some Social Categories. Current Anthropology 42(4):515-54.

Glazer, N., and D. P. Moynihan (eds.). 1975. Ethnicity: Theory and Experience. Cambridge MA.

Haudricourt, A. G. 1962. Domestication des animaux, culture des plantes et traitement d'autrui. L'Homme 2(1):40-50.

Jenkins, R. 1997. Rethinking Ethnicity: Arguments and Explorations. London.

Leacock, E. (ed.) 1971. The Culture of Poverty: A Critique. New York.

Levine, H. B. 1999. Reconstructing Ethnicity. Journal of the Royal Anthropological Institute 5(2):165-80.

Lewis, O. 1959. Five Families: Mexican Case Studies in the Culture of Poverty. New York. 
1966. The Culture of Poverty. Scientific American 215(4):3-9.

Lowenhaupt Tsing, A. 1993. In the Realm of the Diamond Queen: Marginality in an Out-of-the-Way Place. Princeton.

Mahmood, C. K., and S. L. Armstrong. 1992. Do Ethnic Groups Exist? A Cognitive Perspective on the Concept of Cultures. Ethnology 31(1):1-14.

Malinowski, B. 1954. Magic, Science and Religion and Other Essays. Garden City NY.

Marie, A. 1981. Marginalité et conditions sociales du prolétariat urbain en Afrique. Les approches du concept de marginalité et son évaluation critique. Cahiers d'Études Africaines 21(1-3):81-83, 347-74.

Orobitg Canal, G. 1997. Les Pumé et leurs rêves: Etude d'un groupe indien des Plaines du Venezuela. Paris.

Pitt-Rivers, J. 1965. Who Are the Indians? Encounter 25(3):41-49.

1967. Race, Color, and Class in Central America and the Andes. Daedalus 96(2):542-59.

Scott, J. 1990. Domination and the Arts of Resistance-The Hidden Transcripts. New Haven.

Shils, E. 1957. Primordial, Personal, Sacred and Civil Ties. British Journal of Sociology 8(2):130-45.

Taylor, A.-C. 1991. Ethnie. Dictionnaire de l'ethnologie et de l'anthropologie, eds. P. Bonte and M. Izard, pp. 242-44. Paris.

Warren, K. 1992. Transforming Memories and Histories: The Meanings of Ethnic Resurgence for Mayan Indians. Americas: New Interpretative Essays, ed. A. Stepan, pp. 189-219. New York.

Weber, M. 1968. Economy and Society. New York.

Wolf, E. 1994. Perilous Ideas: Race, Culture, People. Current Anthropology 35(1):1-12. 